\title{
MEAN PERFORMANCE AND HERITABILITY STUDIES OF SOME RIDGE Gourd (Luffa acutangula L.) GENOTYPES
}

\section{Nusrat Jahan Methela ${ }^{1}$, Mohammad Shafiqul Islam ${ }^{1 *}$, Nazmunnahar Mitu ${ }^{2}$ and Md. Abdul Latif ${ }^{2}$}

1Department of Agriculture, Faculty of Science, Noakhali Science and Technology University, Noakhali-3814, Bangladesh; 'Department of Genetics and Plant Breeding, Faculty of Agriculture, Patuakhali Science and Technology University, Patuakhali-8602, Bangladesh.

*Corresponding author: Mohammad Shafiqul Islam; E-mail: shafik.ag@nstu.edu.bd

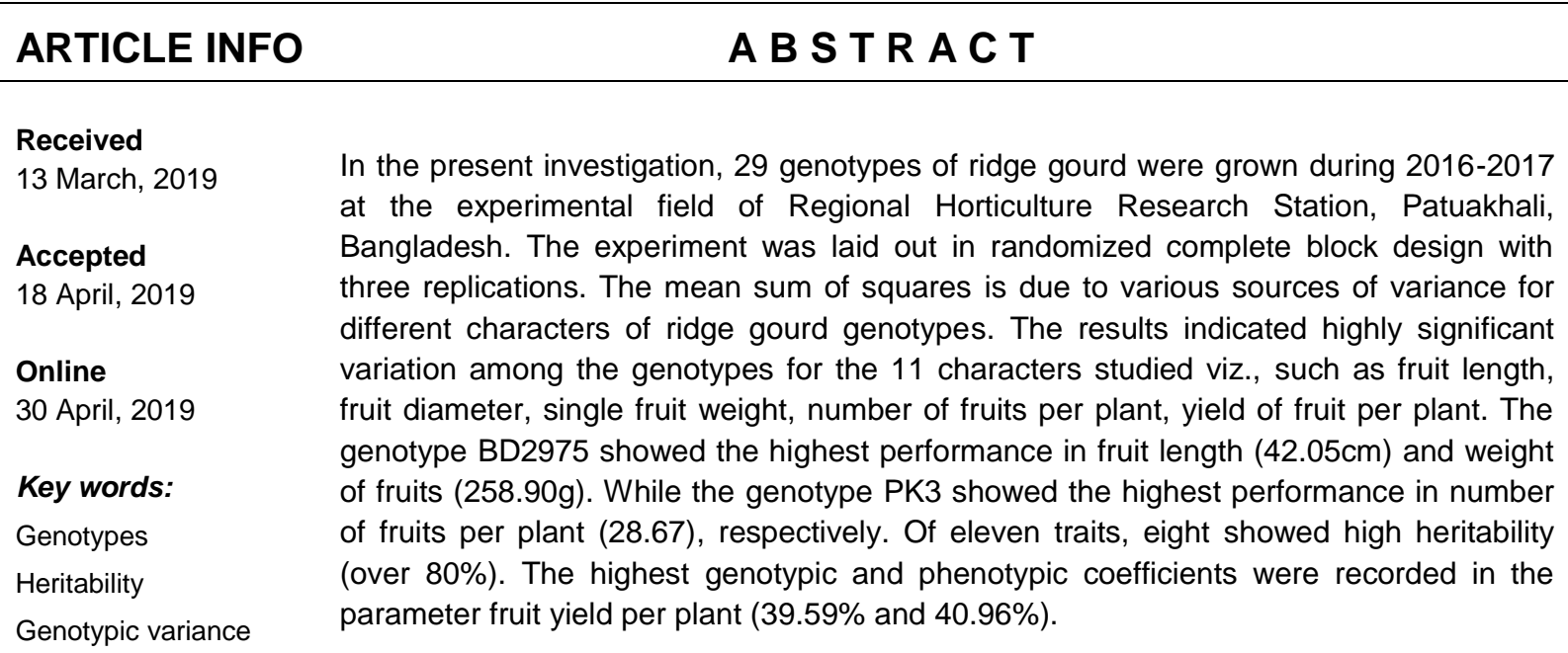

Phenotypic variance

Genetic advance

To cite this article: Methela N. J., M. S. Islam, N. Mitu and M. A. Latif, 2019. Mean performance and heritability studies of some ridge gourd (Luffa acutangula L.) genotypes. Res. Agric. Livest. Fish. 6 (1): 45-55. 


\section{INTRODUCTION}

Ridge gourd (Luffa acutangula L.) is one of the most popular cucurbitaceous vegetable having chromosome number $2 n=26$. It is a monoecious and highly cross pollinated crop in which a large amount of variations are observed for most of the economically important traits. Variability found in shape, size and colour of fruits is most conspicuous. Genetic resources use can be highly enhanced through characterization and evaluation. Characterization of genetic resources is regarded as an important activity for gene banks. It involves determining the expression of highly heritable characters, ranging from morphological features to seed proteins and possibly including molecular markers. Such characters enable easy and quick discrimination among phenotypes and allow simple grouping of the accessions (Engels and Visser, 2003). In addition to morphological markers, scoring of such characters allows establishment of systematic relationship among accessions. This directly facilitates utilization of collections and allows detection of misidentification (Bretting and Widrlechner, 1995). It also results in a better insight in the composition of a collection and the coverage of genetic diversity. Knowledge of the amount of variability and heritability aids the crop breeder for effecting improvement in any crop by choosing suitable breeding technique. This necessitates the evaluation of the assemblage for various requirements in the single environment. Therefore, occurrence of adequate genetic variability is an essential pre-requisite for all crop improvement programmes. The source material for genetically improvement would be identified by studying the amount of variability available in the gene pool or germplasm.

\section{MATERIALS AND METHODS}

\section{Experimental site and genotypes}

This experiment was conducted during the period of 2015-16 at Regional Horticulture Research Station (RHRS), Patuakhali, Bangladesh. The soil was silty clay loam having $\mathrm{pH}$ value of 6.8 . In this experiment, twenty-nine genotypes were used as test crop. Of these, twenty genotypes (BD2982, BD2975, BD2978, BD2981, BD2985, BD2992, BD2883, BD2994, BD2995, BD2997, BD2999, BD3000, BD3001, BD3007, BD3012, BD3017, BD3018, BD3028, BD3031 and BD3040) were obtained from PGRC, BARI, Gazipur. Eight local genotypes (PK1, PK2, PK3, PK4, PK5, PK6, PK8, PK9) were collected from different parts of southern Bangladesh and one (BARI Jhinga-1) check variety was collected from RHRS, Patuakhali. Treated seed were sowed and 15 days old seedlings were transplanted in the main field with recommended spacing $\left(1.5 \times 1.5 \mathrm{~m}^{2}\right)$ following RCBD with 3 replications. Proper management practices were done.

\section{Data collection}

Data were collected in respect of the following parameters to assess plant growth; yield attributes and yields as influenced by different treatments of the experiment.

\section{Plant height (cm)}

Plant height was measured in centimeter $(\mathrm{cm})$ by a meter scale at harvest from the point of attachment of the leaf to the ground level up to the tip.

\section{Days to $1^{\text {st }}$ male flowering and $1^{\text {st }}$ female flowering}

Days to first male flowering and first female flowering were counted when plants of a plot produced first male flower and first female flower respectively.

\section{Fruit length, diameter, thickness (cm)}

Fruit length, diameter, thickness were measured and expressed in centimeter.

\section{Number of fruits per plant}

Average number of fruits produced per plant was recorded for the whole growing period and expressed in fruits per plant. 
Individual fruit weight (g)

The weight of individual fruit was measured and average weight was expressed in gram.

Fruit yield per plant $(\mathrm{g})$ and weight of 100 seeds $(\mathrm{g})$

Total fruit produced for the whole growing period by a plant and Cleaned 100 seeds were weighed, and then recorded in gram.

Total soluble solids (TSS) ( $\left.{ }^{\circ} \mathrm{brix}, \%\right)$

The sugar contents of individual fruits were determined by using hand held refractometer.

\section{Analysis of variance (ANOVA)}

The collected data were statistically analyzed with Duncan's Multiple Range test (DMRT) following Steel and Torrie (1960). Least Significance Difference (LSD) test was evaluated for the interpretation of the results (Gomez and Gomez, 1984). Univariate analysis of the individual character (analysis of variance) was done by computer using STAR (Statistical Tools for Agricultural Research) software.

\section{Estimation of genotypic and phenotypic variances}

Genotypic and phenotypic variances were estimated according to the formula given by Johnson et al. (1955)

Genotypic variance,
$r=$ replication no.

Phenotypic variance, $\sigma_{\mathrm{ph}}^{2}=\sigma_{\mathrm{g}}^{2}+\mathrm{EM} \mathrm{S}$ or $\sigma_{\mathrm{ph}}^{2}=\sigma_{\mathrm{g}}^{2}+\mathrm{EM} \mathrm{S}$

Estimation of genotypic co-efficient of variation (GCV) and phenotypic co-efficient of variation (PCV)

Genotypic and phenotypic co-efficient of variation were estimated according to Burton, 1952 and Singh and Chaudhury, 1985, respectively.

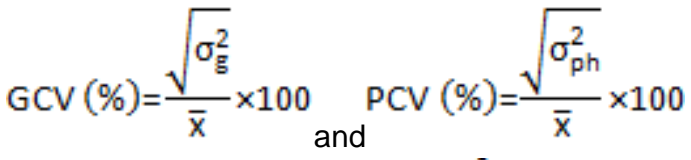

Where, ${ }^{2}=$ Genotypic variance, ${ }^{2}{ }^{2}=$ Phenotypic variance, ${ }^{\bar{x}}=$ Population mean

\section{RESULTS and DISCUSSION}

\section{Yield contributing characters and yield}

\section{Plant height, Days to first male flower and first female flower}

Different genotypes varied significantly for plant height, Days to first male flower and first female flower of ridge gourd (Table 1). The maximum plant height $(988.30 \mathrm{~cm}$ ) was found in BD2985 and the minimum plant height $(492.00 \mathrm{~cm})$ in check variety. The average plant height was recorded $719.43 \mathrm{~cm}$. The plant height of BD2981 $(611.00 \mathrm{~cm})$ and pk6 $(607.70 \mathrm{~cm})$ was statistically similar. The plant height of BD2978 $(582.00 \mathrm{~cm})$ and pk2 $(585.70 \mathrm{~cm})$ was statistically similar. The genotypes BD3031 varied non-significantly with BD2999. Similarly the genotypes BD2999 varied significantly with the genotype BD3018 and BD3018 with BD2992. The maximum days to first male flower (64.33), first female flower (70.33) both were recorded in BD2999 and the minimum (59.33) in days to first male flower, minimum (64.67) in days to first female flower both in PK6. The average days to first male flower and first female flower were recorded 61.55 and 66.33 , respectively. 
Table 1. Mean performance of growth characters of 29 ridge gourd genotypes

\begin{tabular}{|c|c|c|c|c|c|c|}
\hline Genotypes & $\begin{array}{l}\text { Plant height } \\
\text { (cm) }\end{array}$ & $\begin{array}{l}\text { Days to first } \\
\text { male flower }\end{array}$ & $\begin{array}{l}\text { Days to first } \\
\text { female flower }\end{array}$ & $\begin{array}{l}\text { Fruit } \\
\text { length }(\mathrm{cm})\end{array}$ & $\begin{array}{l}\text { Fruit diameter } \\
(\mathrm{cm})\end{array}$ & $\begin{array}{l}\text { Fruit } \\
\text { thickness }(\mathrm{cm})\end{array}$ \\
\hline BD2985 & $988.30 \mathrm{a}$ & $62.00 \mathrm{a}-\mathrm{f}$ & 65.67 cde & $21.40 \mathrm{hi}$ & $4.78 \mathrm{a}-\mathrm{d}$ & $0.30 \mathrm{c}$ \\
\hline BD2993 & $677.30 \mathrm{q}$ & $61.00 \mathrm{~b}-\mathrm{f}$ & 65.67 cde & 26.43 ef & $4.83 \mathrm{a}-\mathrm{d}$ & $0.40 \mathrm{~b}$ \\
\hline BD2972 & $864.00 \mathrm{e}$ & $61.00 \mathrm{~b}-f$ & $66.00 \mathrm{~b}-\mathrm{e}$ & $34.07 \mathrm{~b}$ & $4.75 \mathrm{a}-\mathrm{e}$ & $0.30 \mathrm{c}$ \\
\hline BD2994 & $790.00 \mathrm{j}$ & $64.00 \mathrm{ab}$ & $70.33 \mathrm{a}$ & $22.43 \mathrm{gh}$ & $4.53 \mathrm{~b}-\mathrm{g}$ & $0.30 \mathrm{c}$ \\
\hline BD3031 & $815.30 \mathrm{~g}$ & $61.67 \mathrm{a}-\mathrm{f}$ & $66.33 \mathrm{~b}-\mathrm{e}$ & $18.00 \mathrm{j}$ & $4.03 \mathrm{fgh}$ & $0.29 \mathrm{c}$ \\
\hline BD3007 & $508.30 w$ & $62.33 \mathrm{a}-\mathrm{f}$ & $66.00 \mathrm{~b}-\mathrm{e}$ & $31.17 \mathrm{c}$ & $4.73 \mathrm{a}-\mathrm{e}$ & $0.20 \mathrm{~d}$ \\
\hline PK3 & $618.30 r$ & $59.67 f$ & $65.33 \mathrm{de}$ & 8.731 & $3.43 \mathrm{i}$ & $0.20 \mathrm{~d}$ \\
\hline BD2992 & $805.30 i$ & 60.33 def & $65.33 \mathrm{de}$ & $27.73 \mathrm{de}$ & 4.73 a-e & $0.31 \mathrm{c}$ \\
\hline BD3017 & $760.00 \mathrm{k}$ & $60.67 c-f$ & $66.33 \mathrm{~b}-\mathrm{e}$ & $22.30 \mathrm{gh}$ & $4.77 \mathrm{a}-\mathrm{d}$ & $0.31 \mathrm{c}$ \\
\hline Check variety & $492.00 x$ & $60.67 \mathrm{c}-\mathrm{f}$ & $65.33 \mathrm{de}$ & $30.50 \mathrm{~cd}$ & $4.23 d-h$ & $0.30 \mathrm{c}$ \\
\hline BD3028 & $760.70 \mathrm{k}$ & 62.00 a-f & $69.00 \mathrm{abc}$ & 26.67 e & $4.73 \mathrm{a}-\mathrm{e}$ & $0.19 \mathrm{~d}$ \\
\hline BD2995 & 716.70 o & $61.00 \mathrm{~b}-\mathrm{f}$ & 65.67 cde & $27.37 \mathrm{e}$ & $4.43 \mathrm{~b}-\mathrm{g}$ & $0.51 \mathrm{a}$ \\
\hline BD3001 & $928.30 \mathrm{~b}$ & $63.33 \mathrm{a}-\mathrm{d}$ & $69.00 \mathrm{abc}$ & $23.33 \mathrm{fgh}$ & $5.03 a b$ & $0.31 \mathrm{c}$ \\
\hline BD2999 & $812.00 \mathrm{gh}$ & $64.33 \mathrm{a}$ & $69.33 \mathrm{ab}$ & $14.70 \mathrm{k}$ & 4.67 a-e & $0.31 \mathrm{c}$ \\
\hline BD3018 & $809.00 \mathrm{hi}$ & $62.33 \mathrm{a}-\mathrm{f}$ & $68.33 \mathrm{a}-\mathrm{d}$ & 24.77 efg & $4.50 \mathrm{~b}-\mathrm{g}$ & $0.31 \mathrm{c}$ \\
\hline PK9 & $724.30 n$ & 60.33 def & $66.00 \mathrm{~b}-\mathrm{e}$ & $14.80 \mathrm{k}$ & $4.83 \mathrm{a}-\mathrm{d}$ & $0.40 \mathrm{~b}$ \\
\hline PK1 & $731.00 \mathrm{~m}$ & $59.67 f$ & $66.00 \mathrm{~b}-\mathrm{e}$ & $26.63 \mathrm{e}$ & $4.90 \mathrm{abc}$ & $0.30 \mathrm{c}$ \\
\hline BD3000 & $912.70 \mathrm{c}$ & 62.67 a-f & 67.33 a-e & $30.73 \mathrm{~cd}$ & 3.77 hi & $0.31 \mathrm{c}$ \\
\hline BD3040 & $520.00 \mathrm{v}$ & $62.33 \mathrm{a}-\mathrm{f}$ & 66.67 b-e & 26.17 ef & 4.63 a-f & $0.30 \mathrm{c}$ \\
\hline BD2981 & $611.00 \mathrm{~s}$ & 60.33 def & $66.33 \mathrm{~b}-\mathrm{e}$ & $26.90 \mathrm{e}$ & $4.73 \mathrm{a}-\mathrm{e}$ & $0.40 \mathrm{~b}$ \\
\hline PK2 & $585.70 t$ & $61.33 \mathrm{a}-\mathrm{f}$ & $65.33 \mathrm{de}$ & $27.27 \mathrm{e}$ & $4.00 \mathrm{gh}$ & $0.30 \mathrm{c}$ \\
\hline PK6 & $607.70 \mathrm{~s}$ & $59.33 \mathrm{f}$ & $65.00 \mathrm{de}$ & 25.77 ef & $4.53 \mathrm{~b}-\mathrm{g}$ & $0.30 \mathrm{c}$ \\
\hline PK8 & $557.00 \mathrm{u}$ & 62.00 a-f & $68.33 \mathrm{a}-\mathrm{d}$ & $15.07 \mathrm{k}$ & $4.30 \mathrm{c}-\mathrm{h}$ & $0.41 \mathrm{~b}$ \\
\hline BD2978 & $582.00 t$ & $63.00 \mathrm{a}-\mathrm{e}$ & 67.67 a-e & $18.97 \mathrm{ij}$ & $4.83 \mathrm{a}-\mathrm{d}$ & $0.31 \mathrm{c}$ \\
\hline BD3012 & $744.30 \mathrm{I}$ & 60.00 ef & 65.67 cde & $14.33 \mathrm{k}$ & $4.50 \mathrm{~b}-\mathrm{g}$ & $0.30 \mathrm{c}$ \\
\hline BD2975 & $507.00 \mathrm{w}$ & $61.00 \mathrm{~b}-\mathrm{f}$ & $66.33 \mathrm{~b}-\mathrm{e}$ & $42.07 \mathrm{a}$ & $4.57 \mathrm{~b}-\mathrm{g}$ & $0.30 \mathrm{c}$ \\
\hline PK4 & $697.30 p$ & $63.33 \mathrm{a}-\mathrm{d}$ & 67.00 a-e & $27.83 \mathrm{de}$ & $4.13 \mathrm{e}-\mathrm{h}$ & $0.30 \mathrm{c}$ \\
\hline BD2997 & $850.70 \mathrm{f}$ & 59.67 ef & $64.67 \mathrm{e}$ & $14.27 \mathrm{k}$ & $5.00 a b$ & $0.31 \mathrm{c}$ \\
\hline PK5 & $887.30 \mathrm{~d}$ & $63.67 \mathrm{abc}$ & $69.33 \mathrm{ab}$ & 24.57 efg & $5.20 \mathrm{a}$ & $0.30 \mathrm{c}$ \\
\hline LSD (0.05) & 5.86 & 2.71 & 1.00 & 1.00 & 0.51 & 0.03 \\
\hline
\end{tabular}

Means separated by uncommon letters in order of alphabetic preferences are significantly different from each other at $\mathrm{p}=0.05$ 


\section{Fruit length, diameter, thickness (cm)}

Fruit length, diameter, thickness of ridge gourd varied significantly (Table 1). The longest fruit $(42.05 \mathrm{~cm})$ was recorded in BD2975 and the shortest fruit $(8.73 \mathrm{~cm})$ was observed in PK3 genotypes. The average fruit length was found $23.96 \mathrm{~cm}$. Shinde et al. (2003a) reported that Punjab Sadabahar recorded the greatest average fruit length $(28.73 \mathrm{~cm})$. The highest fruit diameter $(5.20 \mathrm{~cm})$ was recorded from the germplasm PK5 which was closely followed $(5.03 \mathrm{~cm}$ and 5.00$)$ by BD2997 and BD3001, while the lowest fruit diameter (3.43 $\mathrm{cm}$ ) was produced by PK3 genotypes. The average fruit diameter was recorded as $4.56 \mathrm{~cm}$. The maximum fruit thickness $(0.51 \mathrm{~cm})$ was found in BD2995 and the minimum fruit thickness $(0.20 \mathrm{~cm})$ in BD3031, BD3007 and BD3028. The average fruit thickness was recorded as 0.31.The fruit thickness of BD2981, BD2993, PK9 and PK6 were statistically similar.

\section{Number of fruits/plant, Individual fruit weight and Fruit yield/plant}

Different genotypes varied significantly in terms of number of fruits/plant of ridge gourd (Table 2). The maximum number of fruits/plant (28.67) was observed in PK3 and the minimum number (6.00) was observed in PK4 genotypes. The average number of fruits/plant was found 14.2. The highest individual weight of fruit weight $(258.90 \mathrm{~g}$ ) was obtained in BD2975 .which was related to BD3018 and BD3000 and the lowest weight $(43.77 \mathrm{~g})$ in PK3. The average weight of individual fruit was $157.71 \mathrm{~g}$. Shinde et al. (2003a) reported that Punjab Sadabahar produced highest fruit weight $(115.33 \mathrm{~g})$. In case of fruit yield/plant, the average fruit yield/plant was found $2.13 \mathrm{~kg}$. The highest fruit yield/plant $(4.41 \mathrm{~kg})$ was found in BD3000 which was significantly different from all other genotypes. The lowest yield/plant $(0.77 \mathrm{~kg})$ was found in PK4 genotypes. Shinde et al. (2003b) recorded the highest yield with $1.76 \mathrm{~kg} / \mathrm{vine}$.

\section{Weight of 100 seeds and TSS}

Weight of 100 seeds of ridge gourd varied significantly due to different genotypes (Table 2). The average weight of 100 seeds was recorded to be $26.17 \mathrm{~g}$ and the highest weight of 100 seeds $(36.00 \mathrm{~g})$ was attained in check variety and the lowest weight $(7.00 \mathrm{~g})$ was observed in BD2993. The highest TSS was recorded to be 5.67 in BD3017 and the lowest TSS (3.57) was attained in BD2975 and the average of TSS was 4.45.

\section{Analysis of variance of the experimental materials}

The ANOVA of the experimental materials for all the characters of is given in Table 3. Results showed that there were significant variations among the materials for all the characters studied. This shows the presence of considerable genetic variability among the ridge gourd genotypes. Similar finding were reported by Karuppiah et al. (2005), Rao et al. (2002), Singh et al. (2002) and Hegade et al.(2009) in ridge gourd. The morphological traits are controlled by a number of genes and are highly influenced by the environment, whereas molecular markers are not confounded by the environmental effects. For more efficient determination of genetic diversity in ridge gourd genotypes with the morphological traits, molecular system could be utilized. Nevertheless, the information about the genetic diversity in the 29 genotypes of ridge gourd could be successfully utilized in further breeding programs.

Genotype, BD2975 showed maximum fruit length $(42.05 \mathrm{~cm})$ and had highest individual fruit weight (258.90g). PK3 showed shortest fruit $(8.73 \mathrm{~cm})$ but highest number of fruits/plant (28.67). Yield per plant showed maximum deviation from their mean and some of the traits like fruit weight, fruit length and number of fruits per plant showed significant variation within the genotype indicating the role of environment in expression of these traits. The highest yielded ridge gourd genotype is BD3000 (4.41 $\mathrm{kg})$ which was significantly different from all other genotypes. The lowest yield/plant $(0.77 \mathrm{~kg})$ was found in PK4 genotype. In case of ridge gourd, cluster bearing is important traits and most of the genotypes are very small fruited. Genotype PK3 has cluster bearing character. It is more attractive to consumers (Choudhary et al., 2010). Similar finding were reported by Rao et al. (2002), Singh et al.(2002) and Hegade et al. (2009) in ridge gourd.

\section{Study of variability for yield and yield contributing characters}

Genotypic and phenotypic variance, heritability, genetic advance and genetic advance in percentage of mean were estimated and presented in Table 4 and 5. 
Table 2. Mean performance of growth, yield and quality characters of 29 ridge gourd genotypes

\begin{tabular}{|c|c|c|c|c|c|}
\hline Genotypes & $\begin{array}{l}\text { Number of fruits } \\
\text { per plant }\end{array}$ & $\begin{array}{l}\text { Individual fruit } \\
\text { weight (g) }\end{array}$ & $\begin{array}{l}\text { Fruit Yield per } \\
\text { plant }(\mathbf{k g})\end{array}$ & $\begin{array}{l}100 \text { seed } \\
\text { weight }(g)\end{array}$ & $\begin{array}{l}\text { Total soluble } \\
\text { solid (\%) }\end{array}$ \\
\hline BD2985 & $10.67 \mathrm{j}-\mathrm{m}$ & $138.70 \mathrm{ij}$ & $1.48 \mathrm{jkl}$ & $30.00 \mathrm{f}$ & $4.00 \mathrm{e}$ \\
\hline BD2993 & $12.33 \mathrm{~g}-1$ & $190.30 \mathrm{~d}$ & $2.35 \mathrm{fgh}$ & $7.00 \mathrm{q}$ & $4.00 \mathrm{e}$ \\
\hline BD2972 & 13.00 e-k & $210.70 \mathrm{c}$ & 2.73 ef & 24.001 & $4.00 \mathrm{e}$ \\
\hline BD2994 & $10.00 \mathrm{klm}$ & 181.60 ef & $1.81 \mathrm{~cd}$ & $33.00 \mathrm{~d}$ & $4.07 \mathrm{e}$ \\
\hline BD3031 & 14.67 e-h & $214.70 \mathrm{c}$ & $3.15 \mathrm{ghi}$ & $30.00 \mathrm{f}$ & $4.00 \mathrm{e}$ \\
\hline BD3007 & 13.00 e-k & $159.00 \mathrm{~h}$ & $2.07 \mathrm{ghi}$ & $23.00 \mathrm{~m}$ & $5.00 \mathrm{c}$ \\
\hline PK3 & $28.67 \mathrm{a}$ & 43.77 o & $1.25 \mathrm{I}$ & $35.00 \mathrm{~b}$ & $4.00 \mathrm{e}$ \\
\hline BD2992 & $10.67 \mathrm{j}-\mathrm{m}$ & $133.30 \mathrm{jk}$ & 1.42 jkl & 20.000 & $5.00 \mathrm{c}$ \\
\hline BD3017 & $11.00 \mathrm{j}-\mathrm{m}$ & $186.90 \mathrm{de}$ & $2.05 \mathrm{ghi}$ & $26.00 \mathrm{j}$ & $5.67 \mathrm{a}$ \\
\hline Check variety & $25.00 \mathrm{~b}$ & $158.70 \mathrm{~h}$ & $3.95 b$ & $36.00 \mathrm{a}$ & $4.00 \mathrm{e}$ \\
\hline BD3028 & 14.67 e-h & $175.70 \mathrm{fg}$ & 2.57 ef & $22.00 \mathrm{n}$ & $5.00 \mathrm{c}$ \\
\hline BD2995 & $14.33 \mathrm{e}-\mathrm{i}$ & $169.40 \mathrm{~g}$ & $2.43 \mathrm{fg}$ & $33.00 \mathrm{~d}$ & $4.33 \mathrm{de}$ \\
\hline BD3001 & $10.33 \mathrm{klm}$ & $193.20 \mathrm{~d}$ & $1.98 \mathrm{hi}$ & $27.00 \mathrm{i}$ & $4.00 \mathrm{e}$ \\
\hline BD2999 & $17.67 \mathrm{~cd}$ & $161.00 \mathrm{~h}$ & $2.84 \mathrm{de}$ & 20.000 & $5.00 \mathrm{c}$ \\
\hline BD3018 & $11.33 \mathrm{i}-\mathrm{m}$ & $227.10 \mathrm{~b}$ & 2.57 ef & $25.00 \mathrm{k}$ & $4.00 \mathrm{e}$ \\
\hline PK9 & 15.67 def & $87.67 \mathrm{~m}$ & $1.37 \mathrm{kl}$ & $34.00 \mathrm{c}$ & $4.50 \mathrm{~d}$ \\
\hline PK1 & $16.00 \mathrm{de}$ & $88.23 \mathrm{~m}$ & $1.41 \mathrm{jkl}$ & $29.00 \mathrm{~g}$ & $5.50 a b$ \\
\hline BD3000 & $19.67 \mathrm{c}$ & $224.10 \mathrm{~b}$ & $4.41 \mathrm{a}$ & $26.00 \mathrm{j}$ & $4.00 \mathrm{e}$ \\
\hline BD3040 & $15.00 \mathrm{~d}-\mathrm{g}$ & $174.80 \mathrm{fg}$ & 2.62 ef & $27.00 i$ & $5.20 \mathrm{bc}$ \\
\hline BD2981 & $8.67 \mathrm{~m}$ & $168.30 \mathrm{~g}$ & $1.46 \mathrm{jkl}$ & 20.67 o & $4.00 \mathrm{e}$ \\
\hline PK2 & $13.67 \mathrm{e}-\mathrm{j}$ & $145.00 \mathrm{i}$ & $1.98 \mathrm{hi}$ & $28.00 \mathrm{~h}$ & $5.00 \mathrm{c}$ \\
\hline PK6 & 13.00 e-k & $117.20 \mathrm{I}$ & $1.52 \mathrm{jkl}$ & 20.000 & $5.00 \mathrm{c}$ \\
\hline PK8 & $20.00 \mathrm{c}$ & $65.33 n$ & $1.30 I$ & 30.67 ef & $4.00 \mathrm{e}$ \\
\hline BD2978 & $12.67 \mathrm{f}-\mathrm{k}$ & $187.30 \mathrm{de}$ & $2.37 \mathrm{fgh}$ & $27.00 \mathrm{i}$ & $5.00 \mathrm{c}$ \\
\hline BD3012 & 11.67 h-m & 111.10 I & $1.29 I$ & $25.00 \mathrm{k}$ & $5.00 \mathrm{c}$ \\
\hline BD2975 & $13.00 \mathrm{e}-\mathrm{k}$ & $258.90 \mathrm{a}$ & $3.36 \mathrm{c}$ & $31.00 \mathrm{e}$ & $3.50 \mathrm{f}$ \\
\hline PK4 & $6.00 n$ & $127.90 \mathrm{k}$ & $0.77 \mathrm{~m}$ & $25.00 \mathrm{k}$ & $4.00 \mathrm{e}$ \\
\hline BD2997 & $15.00 \mathrm{~d}-\mathrm{g}$ & 118.40 I & $1.77 \mathrm{ijk}$ & $17.33 p$ & $4.33 \mathrm{de}$ \\
\hline PK5 & $9.33 \mathrm{Im}$ & $155.30 \mathrm{~h}$ & $1.45 \mathrm{jkl}$ & $27.33 \mathrm{hi}$ & $4.00 \mathrm{e}$ \\
\hline LSD (0.05) & 2.60 & 7.26 & 0.36 & 0.05 & 0.13 \\
\hline
\end{tabular}

Means separated by uncommon letters in order of alphabetic preferences are significantly different from each other at $\mathrm{p}=0.05$ 
Table 3. Analysis of variance of 29 ridge gourd genotypes

\begin{tabular}{|llllll|}
\hline Sources of variation & Replication & Genotype & Error & CV \\
\hline Df & & $\mathbf{2}$ & $\mathbf{2 8}$ & $\mathbf{5 6}$ & \\
\hline \multirow{3}{*}{ Mean sum of } & Plant height (cm) & 98.56 & $58174.65^{* *}$ & 12.83 & 0.50 \\
squares of & Days to first male flower & 17.48 & $5.96^{* *}$ & 2.75 & 2.69 \\
characters & Days to first female flower & 14.53 & $7.03^{* *}$ & 3.012 & 2.60 \\
& Fruit length (cm) & 8.10 & $150.05^{* *}$ & 2.99 & 7.22 \\
& Fruit diameter (cm) & 0.05 & $0.46^{* *}$ & 0.10 & 6.85 \\
& Fruit thickness (cm) & 0.001 & $0.012^{* *}$ & 0.0003 & 5.10 \\
& Fruits per plant & 10.15 & $66.81^{* *}$ & 2.52 & 11.32 \\
& Individual fruit weight (g) & 90.36 & $7459.98^{* *}$ & 19.70 & 2.81 \\
& Fruit yield (g plant ${ }^{-1}$ ) & 0.16 & $2.18^{* *}$ & 0.05 & 10.44 \\
& 100 seed weight (g) & 0.241 & $111.78^{* *}$ & 0.22 & 1.78 \\
& Total soluble solid (TSS) & 0.166 & $0.994^{* *}$ & 0.054 & 5.23 \\
\hline
\end{tabular}

*Significant at $5 \%$ level of probability, ${ }^{* *}$ Significant at $1 \%$ level of probability

\section{Plant height, Days to $1^{\text {st }}$ male and $1^{\text {st }}$ female flowering}

It was revealed that phenotypic variation (194.10) was higher than the genotypic variance (193.27) for indicating minimum environmental influence on this characters which was supported by narrow difference between phenotypic (19.36\%) and genotypic (19.35\%) co-efficient of variation for plant height (Table 4). High heritability (99.93\%) in plant height attached with high genetic advance (286.74\%) and high genetic advance in percentage of mean (39.86). High estimate of heritability and high genetic advance were registered in plant height suggested that this character was predominantly controlled by environment with complex gene interaction.

It was revealed that phenotypic variation $(3.82,4.35)$ were higher than the genotypic variance $(1.07,1.34)$ for indicating high and moderate environmental influence which were supported by narrow difference between phenotypic $(3.18 \%, 3.13 \%)$ and genotypic $(1.07 \%, 1.73 \%)$ co-efficient of variation for days to $1^{\text {st }}$ male flowering and $1^{\text {st }}$ female flowering respectively (Table 4). Low heritability $(28.01 \%)$ in days to $1^{\text {st }}$ male flowering attached with moderate genetic advance (1.13\%) and moderate genetic advance in percentage of mean (1.83). Again, Moderate heritability $(30.78 \%)$ in days to first female flowering attached with moderate genetic advance (1.32\%) and moderate genetic advance in percentage of mean (1.98). Moderate estimate of heritability and moderate genetic advance were registered in days to1st male flowering and first female flowering suggested that this character was predominantly controlled by environment with complex gene interaction.

\section{Fruit length, diameter and thickness}

From the data it was found that the fruit length in terms of phenotypic variation (52.01) were higher than the genotypic variance (49.02) for indicating low environmental influence on this character which was supported by narrow difference between phenotypic (30.09\%) and genotypic (29.22\%) co-efficient of variation (Table 4). Therefore, the breeder must have to simultaneous consideration of genetic work predicted environment for improving the trait. High heritability (94.25\%) for fruit length was attached with high genetic advance (14\%) and high genetic advance in percentage of mean (58.43). As this trait possessed high variation, it was potential for effective selection for further genetic improvement. Singh et al. (2002) recorded high heritability with high genetic advance for fruit length in ridge gourd. Devmore et al. (2010) reported that the nature and magnitude of genetic variability, heritability accompanied with genetic advance as percentage of mean for fruit length in ridge gourd. Gowda (2011) reported high PCV and GCV which were observed for the characters fruit length that indicates maximum variability and offers good scope for improvement by simple selection in ridge gourd. 
Fruit diameter and thickness in respect of phenotypic variation $(0.22,0.00)$ were higher than the genotypic variance $(0.12,0.00)$ for indicating moderate and lowest environmental influence respectively which were supported by narrow difference between phenotypic $(10.29 \%, 20.72 \%)$ and genotypic $(7.60 \%, 19.97 \%)$ coefficient of variation (Table 4). That mean the very close to phenotypic and genotypic variance which indicated that environment had played a little role with little genetic variation among the germplasm of this trait i.e. environmental influence was minimum. Therefore, diameter and thickness of fruit were the inherent potential among 29 germplasm. Moderate heritability was found (54.55\%) for diameter of fruit attached with lowest genetic advance $(0.53 \%)$ and highest genetic advance in percentage of mean (11.57). On contrary, high heritability was found (92.86\%) for thickness of fruit attached with lowest genetic advance $(0.12 \%)$ and highest genetic advance in percentage of mean (39.64).

Table 4. Estimation of statistical and genetic parameters of yield and its contributing traits of 29 ridge gourd genotypes

\begin{tabular}{|l|l|l|l|l|l|l|}
\hline Parameters & $\begin{array}{l}\text { Plant } \\
\text { height }(\mathbf{c m})\end{array}$ & $\begin{array}{l}\text { Days to first } \\
\text { male flower }\end{array}$ & $\begin{array}{l}\text { Days to first } \\
\text { female flower }\end{array}$ & $\begin{array}{l}\text { Fruit length } \\
\text { (cm) }\end{array}$ & $\begin{array}{l}\text { Fruit diameter } \\
\text { (cm) }\end{array}$ & $\begin{array}{l}\text { Fruit thickness } \\
\text { (cm) }\end{array}$ \\
\hline Mean & 719.43 & 61.55 & 66.73 & 23.96 & 4.56 & 0.31 \\
Max & 988.30 & 64.33 & 70.33 & 42.07 & 5.20 & 0.51 \\
Min & 492.00 & 59.33 & 64.67 & 8.73 & 3.43 & 0.19 \\
SD & 139.25 & 1.41 & 1.53 & 7.07 & 0.39 & 0.06 \\
MSS & 58174.65 & 5.96 & 7.03 & 150.05 & 0.46 & 0.012 \\
$\sigma^{2}$ e & 12.83 & 2.75 & 3.012 & 2.99 & 0.1 & 0.0003 \\
CV (\%) & 0.5 & 2.69 & 2.6 & 7.22 & 6.85 & 5.1 \\
$\sigma^{2}$ g & 193.27 & 1.07 & 1.34 & 49.02 & 0.12 & 0.00 \\
$\sigma^{2} p$ & 194.10 & 3.82 & 4.35 & 52.01 & 0.22 & 0.00 \\
GCV (\%) & $\mathbf{1 9 . 3 5}$ & 1.68 & 1.73 & $\mathbf{2 9 . 2 2}$ & 7.60 & $\mathbf{1 9 . 9 7}$ \\
PCV (\%) & $\mathbf{1 9 . 3 6}$ & 3.18 & 3.13 & $\mathbf{3 0 . 0 9}$ & 10.29 & $\mathbf{2 0 . 7 2}$ \\
ECV (\%) & 0.50 & 2.69 & 2.60 & 7.22 & 6.94 & 5.54 \\
h² (\%) & 99.93 & 28.01 & 30.78 & $\mathbf{9 4 . 2 5}$ & 54.55 & $\mathbf{9 2 . 8 6}$ \\
GA (5\%) & $\mathbf{2 8 6 . 7 4}$ & 1.13 & 1.32 & 14.00 & 0.53 & 0.12 \\
GAPM & $\mathbf{3 9 . 8 6}$ & 1.83 & 1.98 & $\mathbf{5 8 . 4 3}$ & 11.57 & $\mathbf{3 9 . 6 4}$ \\
\hline
\end{tabular}

${ }^{* *}$ Significance at $1 \%$ level, MSS= Mean sum of square, CV $(\%)=$ Coefficient of variation, $\sigma^{2}=$ Environmental variance, $\sigma^{2} g=$ Genotypic variance, $\sigma_{p}^{2}=$ Phenotypic variance, GCV $(\%)=$ Genotypic coefficients of variations, PCV (\%) = Phenotypic coefficients of variations, ECV $(\%)=$ Environmental coefficients of variations, $h^{2} b(\%)=$ Heritability in broad sense, GA $(5 \%)=$ Genetic advance and GAPM= Genetic advance as percent mean.

\section{Number of fruits/plant, Individual fruit weight and Fruit yield/plant}

It was revealed that number of fruits/plant in terms of phenotypic variation $(23.95,2499.79)$ was higher than the genotypic variance $(21.43,2480.09)$ for indicating low environmental influence on this characters which was supported by narrow difference between phenotypic (34.90\%, 31.70\%) and genotypic (33.01\%, $31.58 \%$ ) co-efficient of variation (Table 5). The difference between phenotypic and genotypic variation then was high indicated minimum influence of the environment for the expression of the characters. Therefore, the breeder must have to simultaneous consideration of genetic work predicted environment for improving the trait. High heritability was found $(89.48 \%, 99.21 \%)$ for number of fruits/plant attached with high genetic advance $(9.02 \%, 102.18 \%)$ and highest genetic advance in percentage of mean $(64.32,64.79)$.

In terms of fruit yield/plant the difference between phenotypic variation (0.76) and genotypic variance (0.81) was minimum for indicating minimum environmental influence on this characters which was supported by narrow difference between phenotypic (40.96\%) and genotypic (39.59\%) co-efficient of variation (Table 5). The difference between phenotypic and genotypic variation was minimum which indicated low influence of the 
environment for the expression of this character. Therefore, the breeder must have to consecutive consideration of genetic work predicted environment for improving the trait. High heritability was found $(93.42 \%)$ for fruit yield/plant attached with low genetic advance $(1.68 \%)$ and high genetic advance in percentage of mean (78.82).

As these traits possessed high variation, it was potential for effective selection for further genetic improvement. Singh et al. (2002), Gautham et al. (2004) recorded high heritability with high genetic advance for fruits/plant, individual fruit weight and Fruit yield/ plant. Gowda (2011) reported high PCV and GCV which were observed for the characters number of fruits/plant, individual fruit weight and Fruit yield/ plant that indicated maximum variability and offers good scope for improvement by simple selection in ridge gourd. The high heritability estimate coupled with high expected genetic advance for this trait indicated the importance of both additive and non-additive gene effects for controlling the character is very high.

\section{Weight of 100 seeds and TSS}

Weight of 100 seeds and TSS in terms of phenotypic variation $(37.41,0.37)$ were higher than the genotypic variance $(37.19,0.37)$ for indicating low environmental influence on this characters which was supported by narrow difference between phenotypic (23.37\%, $13.61 \%)$ and genotypic $(23.19 \%, 12.57 \%)$ coefficient of variation (Table 5). The difference between phenotypic and genotypic variation then was indicated low influence of the environment for the expression of the traits. Therefore, the breeder must have to synchronize consideration of genetic work predicted environment for improving the trait. High heritability were found $(99.41 \%, 85.30 \%)$ for weight of 100 seeds and TSS, attached with high genetic advance $(12.53 \%)$ and with low genetic advance (1.06\%), respectively and high genetic advance in percentage of mean (47.86, 23.92). As this trait possessed high variation, it was potential for effective selection for further genetic improvement. Singh et al. (2002) recorded high heritability with high genetic advance for 100 -seed weight.

Table 5. Estimation of statistical and genetic parameters of yield and its contributing traits of 29 ridge gourd genotypes

\begin{tabular}{|c|c|c|c|c|c|}
\hline Parameters & $\begin{array}{l}\text { Number of } \\
\text { fruits per } \\
\text { plant }\end{array}$ & $\begin{array}{l}\text { Individual fruit } \\
\text { weight }(g)\end{array}$ & $\begin{array}{l}\text { Fruit Yield per } \\
\text { plant }(\mathrm{kg})\end{array}$ & $\begin{array}{l}100 \text { seed } \\
\text { weight }(\mathrm{g})\end{array}$ & $\begin{array}{l}\text { Total soluble } \\
\text { solid (\%) }\end{array}$ \\
\hline Mean & 14.02 & 157.71 & 2.13 & 26.17 & 4.45 \\
\hline Max & 28.67 & 258.90 & 4.41 & 36.00 & 5.67 \\
\hline Min & 6.00 & 43.77 & 0.77 & 7.00 & 3.50 \\
\hline SD & 4.72 & 49.87 & 0.85 & 6.10 & 0.58 \\
\hline MSS & 66.81 & 7459.98 & 2.18 & 111.78 & 0.994 \\
\hline$\sigma^{2} e$ & 2.52 & 19.7 & 0.05 & 0.22 & 0.054 \\
\hline CV (\%) & 11.32 & 2.81 & 10.44 & 1.78 & 5.23 \\
\hline$\sigma^{2} g$ & 21.43 & 2480.09 & 0.71 & 37.19 & 0.31 \\
\hline$\sigma^{2} p$ & 23.95 & 2499.79 & 0.76 & 37.41 & 0.37 \\
\hline GCV (\%) & 33.01 & 31.58 & 39.59 & 23.30 & 12.57 \\
\hline PCV (\%) & 34.90 & 31.70 & 40.96 & 23.37 & 13.61 \\
\hline ECV (\%) & 11.32 & 2.81 & 10.50 & 1.79 & 5.22 \\
\hline$h^{2} b(\%)$ & 89.48 & 99.21 & 93.42 & 99.41 & 85.30 \\
\hline GA (5\%) & 9.02 & 102.18 & 1.68 & 12.53 & 1.06 \\
\hline GAPM & 64.32 & 64.79 & 78.82 & 47.86 & 23.92 \\
\hline
\end{tabular}

${ }^{* *}$ Significance at $1 \%$ level, MSS= Mean sum of square, $\mathrm{CV}(\%)=$ Coefficient of variation, $\sigma^{2}=$ Environmental variance, $\sigma^{2} \mathrm{~g}=$ Genotypic variance, $\sigma_{p}^{2}=$ Phenotypic variance, GCV $(\%)=$ Genotypic coefficients of variations, PCV $(\%)=$ Phenotypic coefficients of variations, ECV $(\%)=$ Environmental coefficients of variations, $h^{2} b(\%)=$ Heritability in broad sense, GA $(5 \%)=$ Genetic advance and GAPM= Genetic advance as percent mean. 
$h^{2}$ (b.s) is a convenient expression of phenotypic value which serves as a guide for the breeding value of any parent. For improvement of desirable characters, heritability estimate is very essential to assess the relative effect of genotype and environment on a character in order to predict the extent of possible improvement. Therefore, heritability is one of the major indicators of response to selection for a successful breeding program. The heritability estimates above $60 \%$ are considered as high, $30 \%$ to $60 \%$ are moderate and below $30 \%$ as poor (Robinson, 1949). Estimation of selection parameters (Table 4-5) revealed that there was a wide range of genotypic and phenotypic variances. Genotypic variance ranged from 12.83 (plant height) to 0.01 (fruit diameter) and phenotypic variance ranged from 193.27 (plant height) to 0.12 (fruit diameter). Comstock and Moll (1963) reported that the more diverse the environmental population the smaller the estimates of genetic variance which supports the present results of low estimates of genetic variance. The knowledge of the genotypic and phenotypic variances for each character is necessary to construct a definite selection index (Sprague, 1966). As for as the broad sense heritability estimates are concerned, plant height, internode length $(\mathrm{cm})$, fruit length $(\mathrm{cm})$, thickness $(\mathrm{cm})$, number of fruit per plant, individual fruit weight $(\mathrm{g})$, fruit yield per plant $(\mathrm{kg}), 100$ seed weight $(\mathrm{g})$ and total soluble solid (\%) were highly heritable, whereas, days to first female flower and fruit diameter were moderate in heritability. Days to first male flower showed low heritability. The presence of non-allelic interaction played a major role in decreasing $\mathrm{h}^{2}$ estimates for these traits.

\section{CONCLUSION}

The genetic variability studies revealed that the material used in present investigation possessed variability which provides scope for selection by breeder. The genotype BD2975 showed the highest performance in fruit length $(42.05 \mathrm{~cm})$ and weight of fruits $(258.90 \mathrm{~g})$. While the genotype PK3 showed the highest performance in number of fruits per plant (28.67). Wider genetic variability was observed for plant height, fruit length, individual fruit weight and 100 seed weight. This indicated ample scope for genetic improvement of these traits through hybridization and subsequent directional selection. Of eleven traits, eight showed high heritability (over $80 \%$ ). The highest genotypic and phenotypic coefficients were recorded in the parameter fruit yield per plant (39.59\% and 40.96\%). High PCV, GCV, heritability, genetic advance were observed for plant height, fruit length, thickness, fruit numbers/plant, individual fruit weight, yield/plant 100 seed weight and TSS indicating that these characters were least influenced by the environmental effect and were effectively transmitted to progeny.

\section{ACKNOWLEDGEMNT}

The author is thankful to PGRC, BARI, Gazipur and RHRS, Patuakhali for providing quality ridge gourd seeds.

\section{REFERENCES}

1. Bretting PK and Widrlechner MP, 1995. Genetic marker and horticultural germplasm management. Horticultural Science, 30: 1349-1356.

2. Burton GW, 1952. Quantitative inheritance in grass pea. Proceedings of the 6th International Grassland Congress, 1:277-283.

3. Choudhary B R, Pandey S, Singh PK, Singh R, Rai M, 2010. High-yielding satputia. Indian Council of Agricultural Research News (July-September), 16(1): 10.

4. Comstock RE, Moll RH, 1963. Genotype-environment interactions. pp. 164-196. In: W.D. Hansen and H.F. Robinson (ed) Statistical genetics and Plant Breeding. National Acad. Sci. Washington, D.C., 4, 392-394. 
5. Devmore JP, Dhonukshe BL, Thaware B L, Bendale VW, Jadhav BB, Thprat TN, 2010. Genetic variability and heritability studies in ridge gourd. Journal of Maharashtra Agriculture University, 35(1): 163-165.

6. Engels JMM, Visser L (eds.), 2003. A guide to effective management of germplasm collection, IPGRI, Handbook for gene banks, No. 6. IPGRI, Rome.

7. Gautham B, Neeraja G, Reddy IP, 2004. Evaluation of promising hybrids in ridge gourd (Luffa acutangula L.). The Journal of Research ANGRAU, 32(4): 34-38.

8. Gomez KA, Gomez AA, 1984. Statistical Procedure for Agricultural Research (2nd edn. International Rice Research Institute, A Willey Int. Sci., pp. 28-192.

9. Gowda H, 2011. Genetic Variability Studies in Ridge Gourd (Luffa acutangula L.). An M.Sc thesis. University of Horticultural Sciences, Bagalkot, India. pp.148.

10. Hegade VC, Pradeepkumar T, George T E, 2009. Variability and genetic diversity studies in ridge gourd (Luffa acutangula (Roxb) L.) Proceedings of the 21st Kerala Science Congress, Kerala State Council for Science Technology and Environment, Kollam, 37-39.

11. Johnson HW, Robinson HF, Comstock RE, 1955. Estimation of genetic and environmental variability in soybeans. Agronomy Journal, 47: 314-318.

12. Karuppaiah P, Kavita R, Kumar PS, 2005. Correlation and analysis in ridge gourd (Luffa acutangula L.). Crop Research Hisar, 29: 490-494.

13. Rao BN, Rao P V, 2002. Heterosis in ridge gourd (Luffa acutangula L.). Journal of Research, 30(1): 11-18.

14. Rao BN, Rao PV and Reddy BMM, 2002. Correlation and path analysis in the segregating population of ridge gourd (Luffa acutangula (Roxb.) L.) Crop Research, 20(2): 338-342.

15. Robinson RW, Jeffrey C (eds.), 1949. Biology and Utilization of the Cucurbitaceae. Cornell University Press, Ithaca, New York.

16. Shinde SJ, Nilangekar RG, Barkule SR, Hingole DG, Kadam AS and Sukase KA, 2003a. Studies on fruit characteristics of different ridge gourd (Luffa acutangula L.) genotypes. Journal of Soils and Crops, 13(1): 52-55.

17. Singh RK, Choudhury BD, 1985. Biometrical Methods in Quantitative Genetic Analysis (rev. edition). Kalyani Publisher, New Delhi, India.

18. Singh RP, Mohan J, Dharmendra S, 2002. Studies on genetic variability and heritability in ridge gourd (Luffa acutangula L.). Agricultural Science Digest, 22(4): 279-280.

19. Sprague GF, 1966. Quantitative genetics in plant improvement. In Kenneth J. Fray (ed) Plant Breeding. lowa State University Press. Ames, pp. 325-347.

20. Steel RGD, Torrie JH, 1960. Principles and Procedures of Statistics. McGraw Hill Book Co. Inc. New York. pp. 107-109. 